\title{
Policy Support and Agricultural Development Within China's First 10 Years of Reform: Strategies and Achievements
}

\author{
Amarachi O. Ewulonu Wang, Guohua \\ College of Public Administration, Huazhong University of Science and Technology, P.O. Box 1037, Luoyu \\ Road, 430074 Wuhan, Hubei, P. R. China
}

The authors are grateful to the Chinese Scholarship Council (CSC) for supporting this work through the Chinese University Programme (CUP) PhD Scholarship (2017GXZ024554).

\section{Abstract}

The utilization of agricultural resources to satisfy the basic needs of man is a great remedy to the worlds challenging problems of food insufficiency, poverty, unemployment and overall economic development among developed countries of the world today. It has been established that agriculture contributes up to $60 \%$ to the world's economy making it the foundation of the world's economy. In China, agricultural policies have played very significant roles in the overall development of their economy. This study aimed at understanding and examining the role policy change in agriculture played over the years in shaping the Chinese agricultural sector. The study revealed how policy change in the Chinese rural agricultural production system occurred, the implementation strategies that were adopted that led to tremendous growth in the Chinese economy and finally revealed lessons learnt within the first 10 years of reform which can serve as a lesson to developing countries.

Keywords: Policy change; agricultural development; household responsibility system; Chinese great reform DOI: 10.7176/PPAR/9-11-06

Publication date: November $30^{\text {th }} 2019$

\section{Introduction}

Policy is a set of ideas that guide the activity of individuals, organizations or group of people towards achieving a defined objective. The growth and development of an organization is dependent on how well polices are implemented. When policies exhaust their usefulness or no longer serve their purposes, they are changed. Most developed countries of the world today can proudly trace back their development to the adoption of certain agricultural policies. Prior to the great reform of over four decades ago, Chinese economy was backward, poor and stagnant (Morrison, 2018). Development in China over the past four decades has passed through various policy transformations which could be traced back to the change in land tenure system where the household responsibility system (contract responsibility system) was used to replace the collective land ownership system (Jiancheng, Jinbao, Shaoyong, \& Qiang, 2008; Lin, 1992; Lopez, He, \& De Falcis, 2017). This was first introduced at the countryside of Anhui Province and later adopted as a nationwide practice (Lau \& Zheng, 2017; Zhao \& Tang, 2018) which brought progressive change in the Chinese agricultural and rural economic sectors leading to sustained development (Jiancheng et al., 2008). Zhao et al as sited above specified that gradual liberalization of prices, de-collectivization, land transfer, liberalization of agricultural products (grains), marketing, improving rural transportation, promoting rural financial development, and providing technical assistance for farmers, masterminded the smooth transformation of Chinese agricultural and rural sectors. China is currently addressed as the fastest growing economy with over $9.7 \%$ economic growth per annum as a result of a sustained growth over four decades (Lau \& Zheng, 2017). Although the real growth rate in the Gross Value of Agricultural Output (GVAO) of $6.1 \%$ per year over the past decades (Gong, 2018) slightly deferred from the $9.7 \%$ economic growth rate. Lau \& Zheng as sited above maintained that agricultural growth after the great reform has remained high and stable. Agriculture in China is said to have accounted for $28.1 \%$ of the gross domestic product absorbing $70.5 \%$ of the nation's working population (Cheng, 2000). Over the years, many countries of the world have invested in the agricultural sector as a means of eradicating hunger, poverty and achieving sustainable development.

The Peoples Republic of China after her economic reform in 1978 adopted certain measures in order to ensure advancement in agriculture to meet the needs of its teeming population. China's agricultural reform ensured the eradication of hunger, achieving food security, improving nutrition and promoting sustainable agriculture which is in line with the number two goal of the United Nations sustainable development goals. China under the Communist Party of China (CPC) led government preaches agricultural modernization with distinctive Chinese characteristics and has maintained a big agricultural sector with a five-year consistent policy pattern that is currently at the $13^{\text {th }}$ year plan. China has recorded high growth in agriculture and rural development, feeding $20 \%$ of the world's population with less than $9 \%$ of the world's arable land (Cheng, 2004).With rapid industrialization, urbanization and technological boom, the contribution of agriculture has dwindled. The share of agriculture in Chinese GDP dropped to $11.8 \%$ and the percentage of the workforce engaged in agriculture declined to $42.6 \%$. Agriculture's share of total exports dropped from $26.7 \%$ in 1980 to 
$3.2 \%$ in 2006, while its share of total imports dropped from $33.8 \%$ to $4 \%$ in the same period (Cheng, 2000). Contemporary, there has been a great quest for sustainable development, poverty eradication and diversification in the world especially among developing countries. This study is keen at understanding how the Chinese policy change occurred, how the economy has been sustained since the great reform with specific concentration within the first 10 years. The strategies adopted and achievements within the first 10 years of implementing the new agricultural policy of the great reform will also be x-rayed in this review.

\subsection{The Chinese Great Reform}

The Chinese great reform targeted at achieving a market-oriented economy was masterminded by Deng Xiaoping in 1978 after he became the leader of the CPC lead government. He introduced an open-door policy that was seen as an extension of the Chinese initial four modernization policy of 1964 (agriculture, industry, science and technology, and defence) which was altered by cultural revolution. The communist party leadership had agreed to open up their boundaries for investment opportunities in the third plenary session of the $11^{\text {th }}$ Central Committee of the CPC which took place in 1978. The Chinese great reform strategy was targeted towards achieving economic reform and modernization of the Chinese economy starting with the agricultural and rural sector with the aim of creating and developing "Socialism with Chinese Characteristics" (Deng Xiaoping, 1984; Tisdell, 2008).

In other words, it can be emphatically said that the great move by Xiaogang farmers who boldly fought against the collectivism agricultural practices that undermined development and food sustainability in their community spearheaded the implementation of the new agricultural policy. This great move coincided with the opening up of the economy by the CPC government who sort for alternatives to economic development by adopting the Xiaogang led agricultural model known as the Household Responsibility System (Chow, 2018; Garnaut, Song, \& Fang, 2018). The government further established Township and Village Enterprises (TVE) that handled surplus goods, managed production and distribution of agricultural products (Hofman, 2018).

\subsection{Chinese Agricultural Development (The Revolution)}

Agricultural development involves all the assistance the agricultural sector receives that give rise to increase in production, distribution and consumption. Policy support in agriculture involves the assistance given to crop producers which protects their interest as well as increase production of crops, distribution and consumption. According to the Organization for Economic Co-operation and Development (OECD) 2017 report, agricultural policies must incorporate the provisions for; food security, improving standard of living among rural dwellers, promoting sustainable production, providing monetary support to producers, training, information and innovation sharing system and physical infrastructure. Rural credit provision has been identified as an important component for agricultural support in developing countries (Ghinoi, Wesz Junior, \& Piras, 2018). Chinese economic reform started with the agricultural and rural sectors as a bottom-up approach triggered by farmers' autonomous self-reform in the rural areas. This witnessed three significant phases; the reform of householdbased land contract system, the rural taxes and fees reform, and the comprehensive rural reform (Li, 2015). This rural reform launched in 1978 has become the historical turning point of Chinese agricultural development (Cheng, 2000).

Historically, the Chinese great reform was initiated in 1978 by Yan Hongchang, a 29-year-old father of 4 living in the Xiaogang village in Anhui local government. Previously, the community practiced collective system of agriculture imposed by the government which discouraged competition and hard work among farmers. The system distributed equal wages to farmers irrespective of their productivity leading to farmers abandoning their farmlands since hard work and output was not equated to their income. Persistent drought ravaged the villages and local crops while hunger and poverty confined people in their homes including cattle that were too weak to plough. This threshold of suffering spurred the Xiaogang villagers to seek an alternative way of survival thereby boycotting the government agricultural system. The household production responsibility system was introduced enabling individuals to keep surplus grain after paying their required taxes to the government. This move attracted applauds, suspicion and all forms of interrogations on Yan but by 1980, Wan Li the Anhui's party Secretary visited to applaud the Yan's initiative which was later known as Xiaogang model (Dandan, 2018; Yuankai, 2005). It was on record that the commune system of production discouraged farmers from engaging in farm activities but with the introduction of the Household Responsibility System, farmer's enthusiasm to work and produce crops was reignited as shown in Figure 1. 


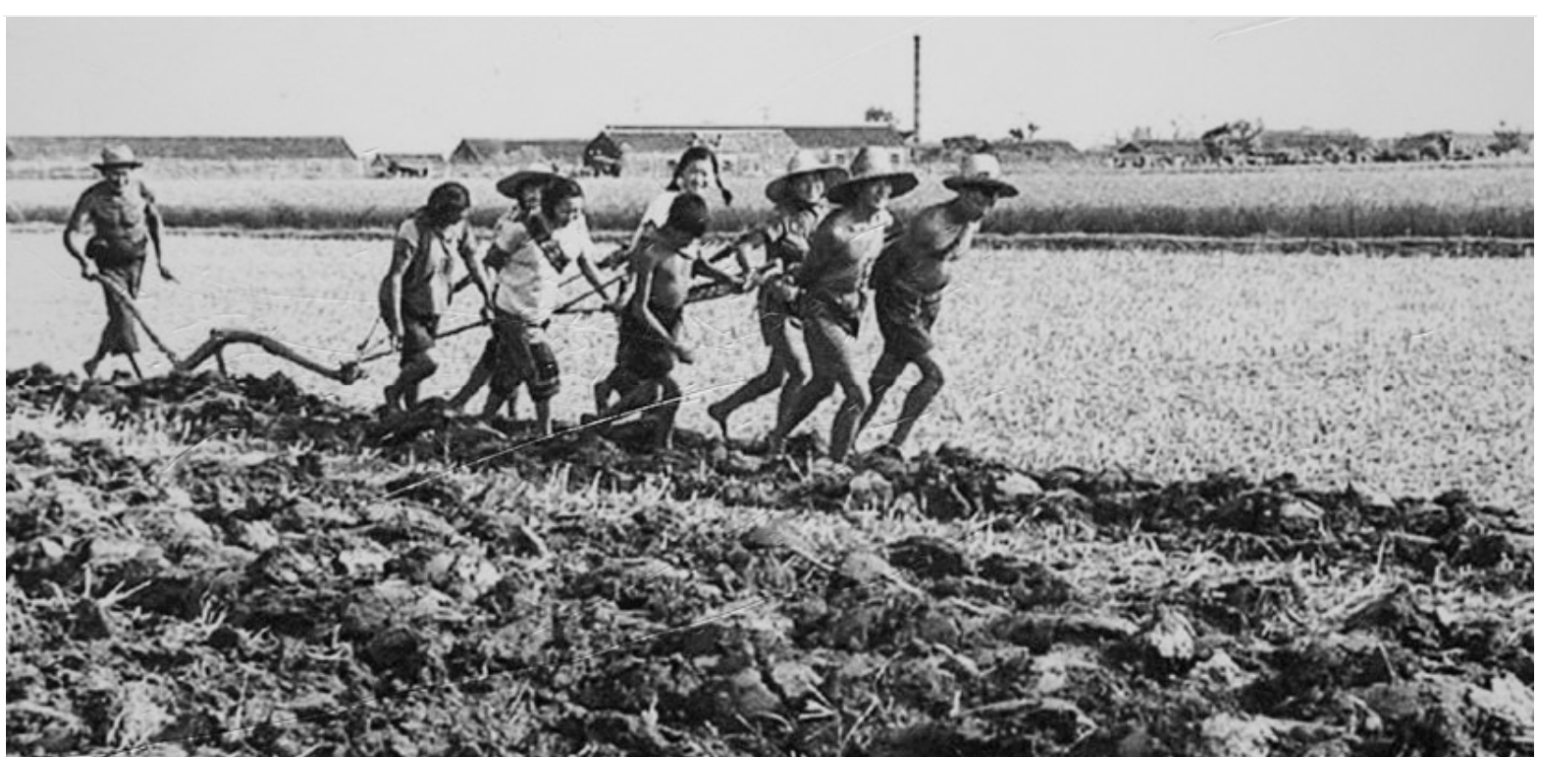

Figure 1: A 1978 Picture showing people of Xiaogang village from Anhui Province tilling a farmland after adopting the household production responsibility system (Dandan, 2018).

The endorsement of the agreement by the representatives of the Xiaogang village (Figure 2) lead to a reported grain yield of about 161 metric tons as against the usual 95 metric tons previously reported. This figure was said to have been deliberately under reported for fear of being victimized by government on falsehood accusation. However, the continuous progress recorded by Xiaogang village encouraged the government to abolish the commune system and adopt the Xiaogang rural agricultural model called the Household Responsibility System (HRS) in 1986. The government later issued a guideline on the implementation of the policy for the benefit of the country. Researchers in agricultural sector have maintained that HRS is compatible with socialism since land use was solely regulated by the state. Farmers contracted lands based on the state's terms and conditions. The process of planning for the production and procurement of cottons, wheat and other agricultural products were controlled by the state as embedded in the implementation guideline issued by government (Douglas Hurt, 2010).

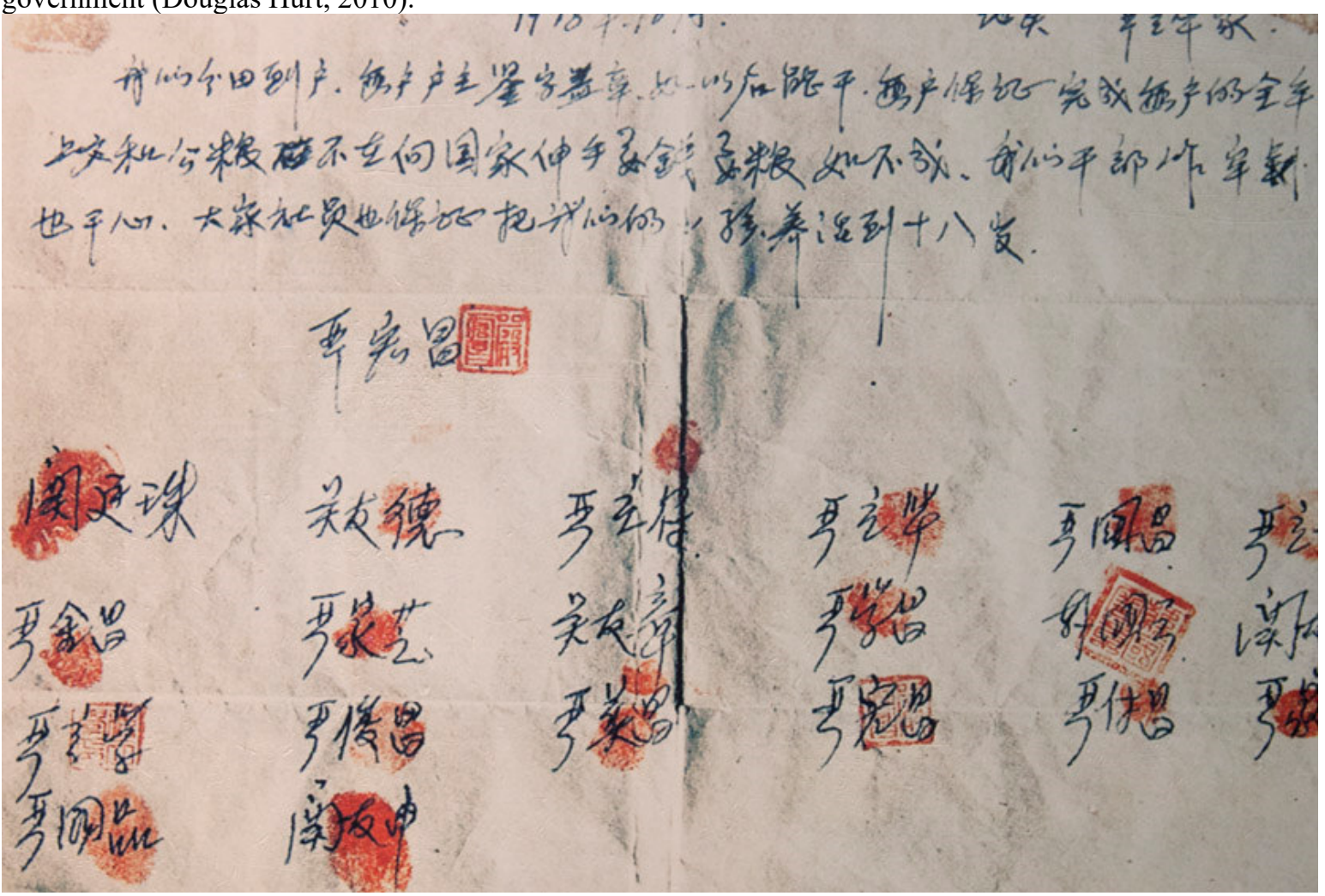

Figure 2: Signature of the representatives from the 20 Xiaogang villages of Anhui province who met and adopted the Household Responsibility System (Dandan, 2018). 
2. Implementation Strategies of The Chinese Agricultural Development Reform Within the First 10 Years of The Reform $(1978-1988)$

Generally, agricultural development in China after the first ten years of the reform period and beyond has been progressive and stable cutting across all the regions in China (Fang, Garnaut, Song, \& River, 2019; Zhou, 2013). Increased productivity led to migration into the non-agricultural sectors in the urban areas despite the ban on migration, and creation of Township and Village Enterprises (TVEs). The increased production in agriculture opened doors for more Foreign Direct Investments (FDIs) that required lots of labour in the urban areas. This however led to lifting of ban on rural-urban migration that enabled lots of rural dwellers to migrate to urban cities (Meng, 2018). The change to household production responsibility system further led to institutional changes that sustained agricultural and rural development in china over the years. Such institutional changes include Village Governance, Agricultural Product Distribution System, and Rural Industrial Structure (Li, 2015). These rural institutional changes gave rise to quick development of rural industries and enterprises as well as increased production of grains like, maize, millet, rice, soy beans, and fruits, vegetables, etc. in commercial quantities. Though, this great reform started from one village, it was not lopsided since it gradually spread across all provinces and regions in the People's Republic of China leading to growth in agricultural production as represented Table 1. Subsequently, the HRS metamorphosed to various reforms that are presently sustaining the Chinese economy such as the rural taxes and fees reform and the comprehensive rural reform.

Table 1: Regional growth indices of agricultural production, $1965=100$ (Shenggan Fan \& Pardey, 1997)

Regional agricultural production growth indices, $1965=100^{\mathrm{a}}$

\begin{tabular}{|c|c|c|c|c|c|c|c|c|}
\hline \multirow[t]{2}{*}{ Year } & \multicolumn{8}{|l|}{ Region $^{b}$} \\
\hline & Northeast & North & Northwest & Central & Southeast & Southwest & South & National \\
\hline 1965 & 100 & 100 & 100 & 100 & 100 & 100 & 100 & 100 \\
\hline 1970 & 135 & 123 & 107 & 115 & 119 & 107 & 113 & 118 \\
\hline 1975 & 160 & 153 & 122 & 135 & 137 & 121 & 134 & 139 \\
\hline 1978 & 167 & 163 & 123 & 148 & 152 & 140 & 152 & 152 \\
\hline 1979 & 168 & 173 & 129 & 163 & 167 & 147 & 155 & 162 \\
\hline 1980 & 180 & 176 & 129 & 153 & 161 & 156 & 167 & 164 \\
\hline 1981 & 185 & 185 & 139 & 166 & 177 & 160 & 177 & 173 \\
\hline 1982 & 193 & 203 & 153 & 186 & 200 & 179 & 204 & 192 \\
\hline 1983 & 233 & 231 & 163 & 190 & 204 & 192 & 210 & 208 \\
\hline 1984 & 251 & 261 & 184 & 212 & 235 & 210 & 226 & 232 \\
\hline 1985 & 231 & 270 & 203 & 224 & 247 & 217 & 251 & 241 \\
\hline 1986 & 251 & 269 & 208 & 234 & 260 & 227 & 264 & 250 \\
\hline 1987 & 261 & 291 & 220 & 244 & 269 & 236 & 285 & 264 \\
\hline 1988 & 279 & 304 & 241 & 243 & 279 & 244 & 299 & 274 \\
\hline 1989 & 257 & 320 & 246 & 256 & 282 & 253 & 322 & 283 \\
\hline 1990 & 319 & 340 & 283 & 268 & 292 & 266 & 345 & 304 \\
\hline 1991 & 328 & 358 & 298 & 276 & 281 & 283 & 368 & 315 \\
\hline 1992 & 351 & 370 & 313 & 293 & 317 & 292 & 401 & 335 \\
\hline 1993 & 384 & 413 & 327 & 311 & 346 & 299 & 428 & 361 \\
\hline
\end{tabular}

Growth rate ${ }^{\mathrm{c}}$

$\begin{array}{lllllllll}1965-78 & 4.0 & 3.8 & 1.7 & 3.1 & 3.3 & 2.6 & 3.3 & 3.3 \\ 1979-84 & 8.4 & 8.6 & 7.4 & 5.5 & 7.0 & 7.4 & 7.8 & 7.5 \\ 1985-93 & 6.6 & 5.4 & 6.1 & 4.1 & 4.3 & 4.1 & 6.9 & 5.2 \\ 1965-93 & 4.9 & 5.2 & 4.3 & 4.1 & 4.5 & 4.0 & 5.3 & 4.7\end{array}$

Institutional changes involving the village governance system which was introduced in 1987 made the farmers to be politically organized leading to their improved welfare (Garnaut \& Song, 2006). This was a good policy strategy through which farmers conquered the centralized system of agricultural production while fully adopting household responsibility system. This further developed farmers into owners of private businesses that gave rise to the improved overall rural economic sector as well as laying the foundation for sustainable agricultural development ( $\mathrm{Li}, 2015)$. On the other hand, agricultural product distribution system was another policy strategy used within the first 10 years of policy change in the framework of HRS. This policy strategy removed the initial restrictions on the flow of agricultural products while enabling rural fair-trading market where agricultural products other than cotton, grain and oil circulated freely in the rural and urban markets (Jiancheng et al., 2008). Moreover, the rural industrial structure change allowed the central government to 
strategically reconstruct the rural industrial structure, making it more adaptive to market realities that gave rise to specialization, commercialization and socialization for agricultural productions (Jiancheng et al., 2008). The increased agricultural production in grain foods and surplus labor in rural areas prompted government to diversify the rural economic structure. Farmers were encouraged to produce more economic crops than monoculture in grain crops. The use of agricultural lands for different agricultural activities was also encouraged ranging from poultry, forestry, animal husbandry to fishery (Jiancheng et al., 2008).

\section{The Household Responsibility System or the Contract System}

Chinese rural reform has passed through three stages of restructuring which are; the household responsibility system, the rural taxes and fees reform and the comprehensive rural reform ( $\mathrm{Li}, 2015)$. However, this study is focused on the first stage of reform which occurred within the first ten years of Chinese policy change. The household responsibility system is the first stage of the Chinese rural reform which focused on agricultural production system and was launched in the early 1980 s by peasant farmers. This system enabled households to contract lands, machineries and other facilities from collective organizations with the aim of preserving the basic integrated management of the communal economy. It suited the nature of agriculture and the stage of development of the productive forces in the rural areas then. Households were able to take decisions independently within the limits set by the contract as well as managing excess production beyond national and collective quotas. HRS which was created by farmers at the grassroot was later supported by the central government enabling it to spread nationwide. Interestingly, $93 \%$ of production teams had adopted this system as of 1983 making households became basic production units with shared lands and full rights in decision-making. Additionally, farmers were responsible for their individual profits and losses, were able to purchase and own everything except land which subsequently led to increased agricultural productivity (Chen \& Brown, 2001). This increased agricultural production facilitated the diversification into non-agricultural sectors leading to high rate of rural-urban migration, mobility of rural labour force, tremendous resource shift, increased industrialization with increased labour force participation (Loren, Hsieh, \& Zhu, 2008).

\section{Achievements of Policy Support in the Agricultural Development of China (1978 - 1988)}

Policy support given to Chinese agricultural system in 1978 transformed their agricultural and rural sectors tremendously leading to rural economic development, feeding nearly $21 \%$ of the world's population with less than $9 \%$ of the world's arable land (Xiao-qiang, Mongol, \& Fu-suo, 2018). The reform of the rural sector encouraged overall reform of China's economic system and facilitated the growth of Chinese economy. China also became a major actor in terms of production and consumption of agricultural products in the international economy. Figure 3 is an illustration of the growth rate in employment and the production sectors with over $65 \%$ growth rate in production and about $60 \%$ growth rate in employment by 1984 .
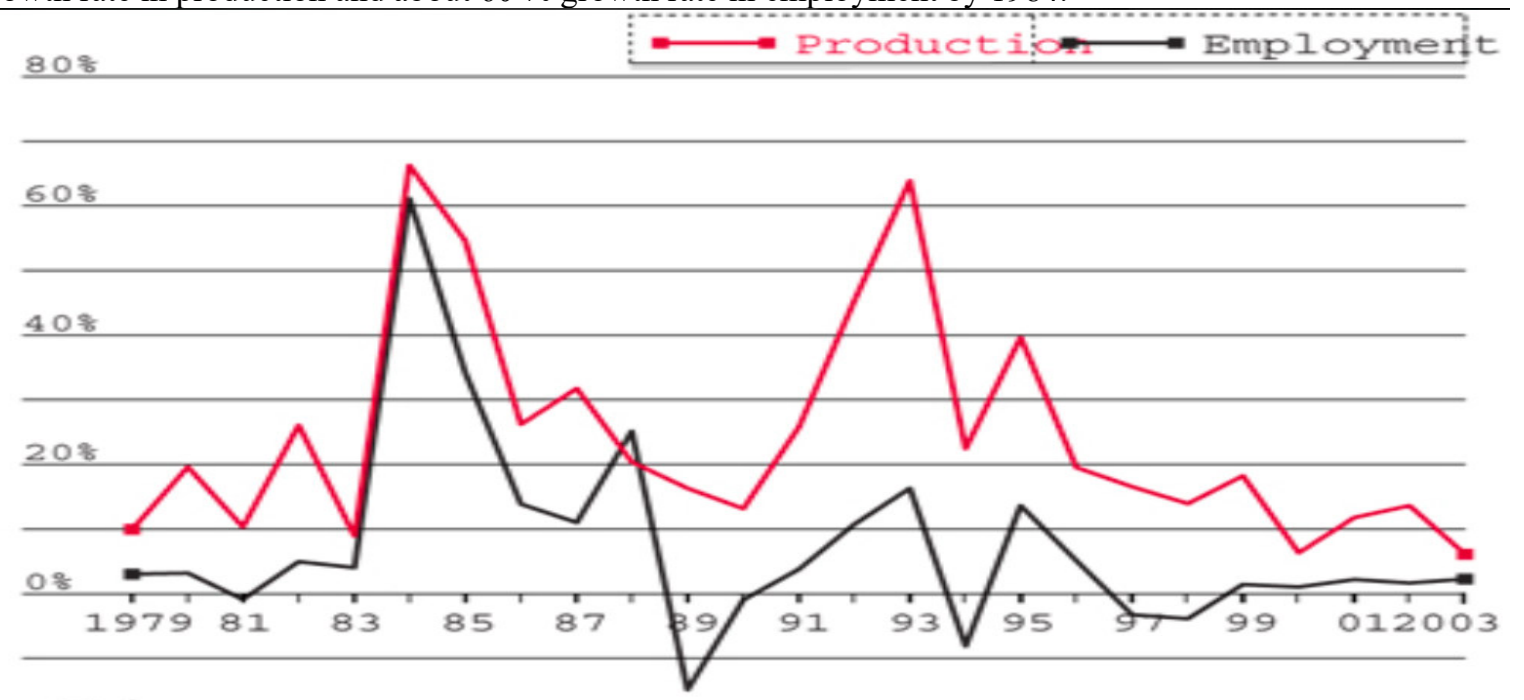

-20 훙

Figure 3: The growth rate of rural enterprises in terms of production and employment output (Yang, 2006).

It is important to note the significant growth in the level of production and employment from 0 to above $60 \%$ after the reform period (Figure 3). This sharp increase may have resulted from the Township and Village Enterprises (TVES) that employed up to 87 million workers in 1987 equivalent to the 100 million employees of State-owned enterprises (SOES) (Ahmad \& Wang, 1991). Ahmad \& Wang (1991), further stated that the rural residents average real per capita net income doubled between 1978 to 1988 while agricultural output grew 
annually at the rate of $6.2 \%$ from 1979 to 1988 as against the $2.7 \%$ growth rate witnessed between 1953 to 1978. These accomplishments resulted from the introduction of HRS between 1978-1984 that further led to the introduction of market liberalization and pricing in agriculture between 1985-1989.

These two major agricultural development policies introduced within the first 10 years after the great reform recorded huge success (Gong, 2018). The boast recorded by these policy initiatives as of 1984 led 14 cities to join the 4 previously established Special Economic Zones (SEZs) by central government under Deng Xiaoping's regime. Additionally, almost all the cities along the Yangtze River and interior border cities joined the SEZs by 1989 to boast the export of their increased production (Fang et al., 2019). Fang et al (2019) further noted that these internal opening up strategies to the global economy were extended to global institutions by 1986 with China's request to resume the status of a contracting party to the General Agreement on Tariffs and Trade (GATT) and later accession to the World Trade Organization (WTO) in 2001. These led to adequate capital accumulation and efficient allocation of physical and human capital serving as a prerequisite for successful economic development. It is noteworthy that the improved policy support from the government to the agricultural sector further attracted increased budgetary allocations (Table 2).

Table 2: China budgetary allocation to agriculture, 19701988

\begin{tabular}{|c|c|c|c|c|c|c|c|}
\hline Year & $\begin{array}{l}\text { Total state } \\
\text { agriculture } \\
\text { expenditures }\end{array}$ & $\begin{array}{c}\text { Share (\%) } \\
\text { of totai } \\
\text { expenditures }\end{array}$ & $\begin{array}{l}\text { Capital } \\
\text { construction } \\
\text { expenditures }\end{array}$ & $\begin{array}{l}\text { Rural } \\
\text { production } \\
\text { support }\end{array}$ & $\begin{array}{l}\text { Working } \\
\text { capital }\end{array}$ & $\begin{array}{l}\text { Trial } \\
\text { product } \\
\text { support }\end{array}$ & Other \\
\hline & Billion yuan & Percent & $-\cdots \cdots$ & $---\cdots$ & Bilion yuan & ------ & --- \\
\hline 1970 & 4.94 & 7.60 & 2.25 & 1.59 & 0.28 & na & 0.82 \\
\hline 1971 & 6.08 & 8.30 & 3.33 & 1.97 & 0.21 & 0.01 & 0.56 \\
\hline 1972 & 6.51 & 8.50 & 3.15 & 2.51 & 0.26 & 0.01 & 0.59 \\
\hline 1973 & 8.52 & 10.50 & 3.75 & 3.55 & 0.30 & 0.00 & 0.91 \\
\hline 1974 & 9.12 & 11.50 & 3.70 & 3.82 & 0.31 & $0.0 T$ & 1.28 \\
\hline 1975 & 9.90 & 12.10 & 3,56 & 4.25 & 0.32 & 0.01 & 1.76 \\
\hline 1976 & 11.05 & 13.70 & 3.99 & 4.60 & 0.45 & 0.08 & 1.93 \\
\hline 1977 & 10.81 & 13.80 & 3.60 & 5.07 & 0.36 & 0.09 & 1.70 \\
\hline 1978 & 15.07 & 13.60 & 5.11 & 7.70 & 0.75 & 0.11 & 1.39 \\
\hline$\$ 979$ & 17.42 & 13.70 & 8.24 & 9.00 & 0.54 & 0.15 & 1.49 \\
\hline 1980 & 15.00 & 12.40 & 4.86 & 8.21 & 0.40 & 0.13 & 1.39 \\
\hline 1981 & 11.02 & 9.90 & 2.42 & 7.37 & 0.22 & 0.12 & 0.91 \\
\hline 1982 & 12.05 & 10.40 & 2.88 & 7.99 & 0.21 & 0.11 & 0.86 \\
\hline 1983 & 13.28 & 10.30 & 3.43 & 8.67 & 0.08 & 0.18 & 0.94 \\
\hline 1984 & 14.13 & 9.10 & 3.36 & 9.59 & na & 0.22 & 0.96 \\
\hline 1985 & 15.36 & 8. 30 & 3,77 & 10.10 & na & 0.20 & 1.29 \\
\hline 1986 & 18.42 & 7.90 & 4.39 & 12.43 & na & 0.27 & 1.33 \\
\hline 1987 & 19.55 & 7.94 & 4.68 & 13.42 & ra & 0.23 & 1.25 \\
\hline 1988 & 15.87 & 5.95 & na & 15.51 & na & na & na \\
\hline
\end{tabular}

Source: Agricultural Statistics of the People's Republic of China, 1949-90

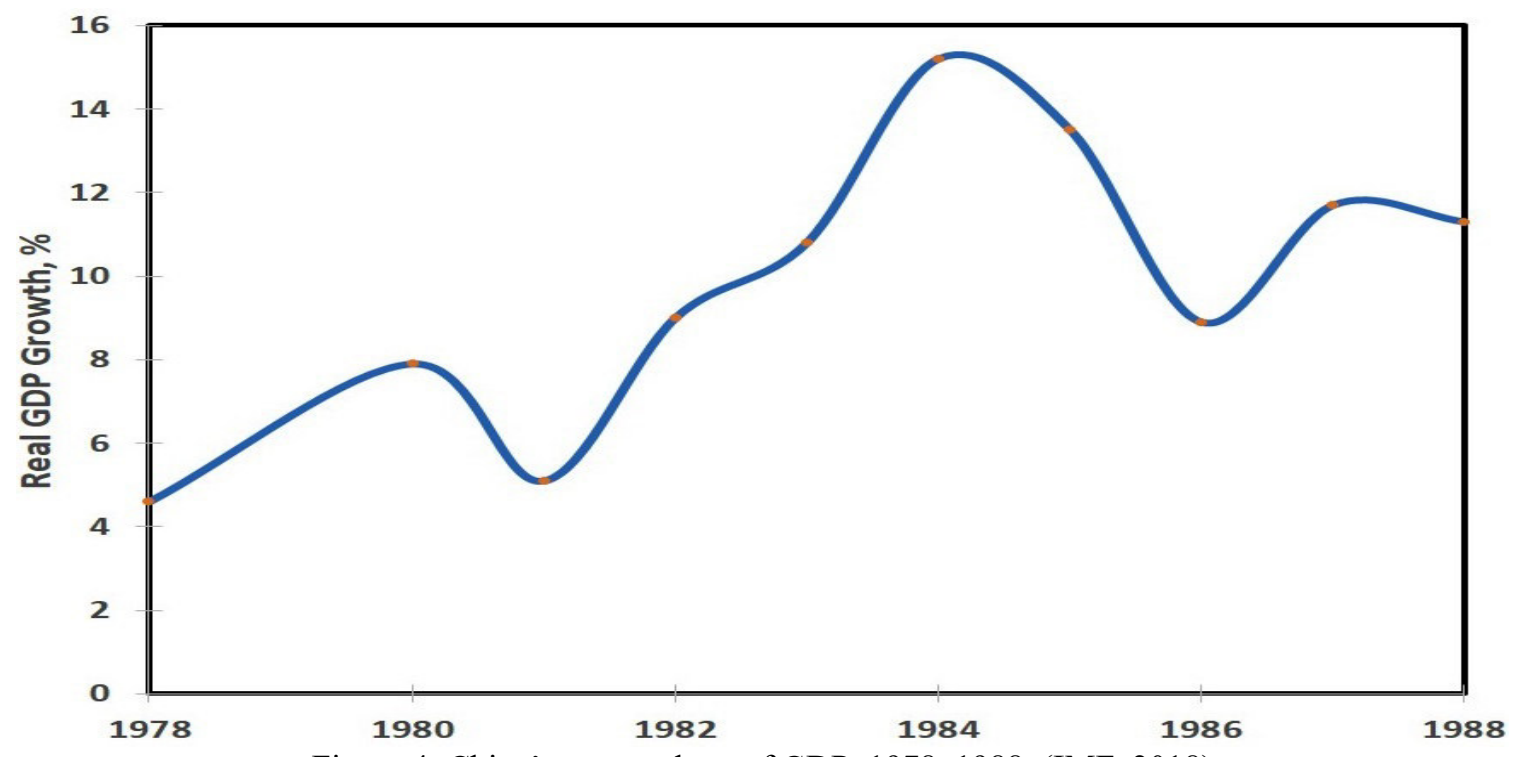

Figure 4: China's export share of GDP, 1978-1988 (IMF, 2018) 
The Chinese export of Gross Domestic Products (GDP) showed significant increase from $4.56 \%$ to $15.30 \%$ within 1978 - 1984 (Figure 4) portraying a constant increase in production and growth of the economy. Moreover, the reform provided increased incentives in agricultural production, granting farmers autonomy over operations and rights to profits leading to efficient management of the lands and labour that in turn gave motivations to raise productivity. Furthermore, the level of poverty reduction after the great reforms in agriculture is illustrated in Figure 5. The figure in agreement with China's export share of GDP (Figure 4) showed that the agricultural reforms led to tremendous reduction in poverty, dramatic increase in output and growth in GDP (Marden, 2015).

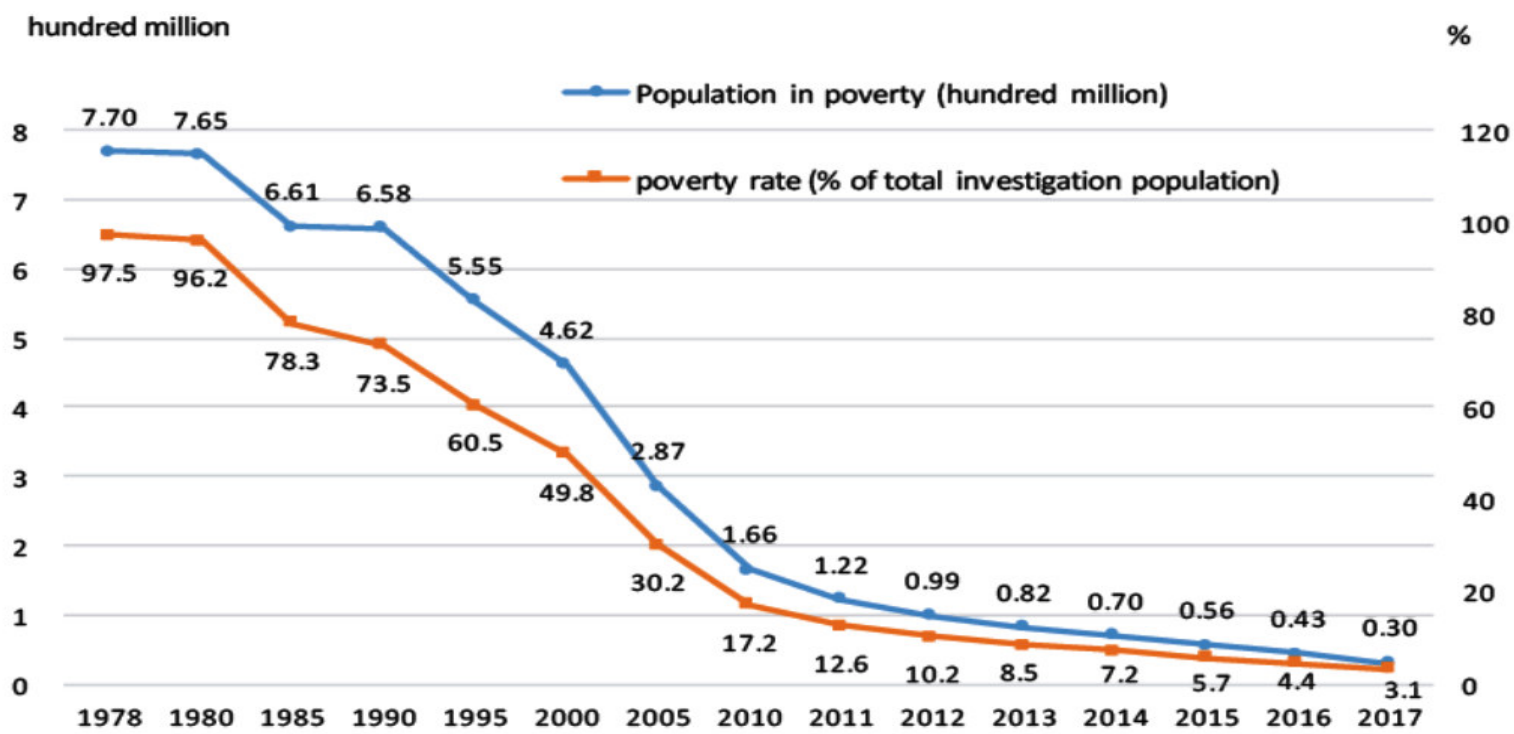

Figure 5: Poverty reduction statistics from 1978 to 2017. Sources: (Fang et al., 2019) referencing the State Council Information Office (2016); National Bureau of Statistics (NBS various years).

Moreover, an illustration of the different contributions of agriculture from $1978-2000$ in GDP share ranging from employment, products exports to share of rural population is presented in Table 3 . It is evident from the table that within the first ten years of the reform, agriculture contributed the highest share in employment with a GDP lower than that of the industrial sector. It is important to note that the enabling agricultural policy framework within this period can also be associated to the higher GDP from the industrial sector. Since the increased agricultural production gave rise to the establishment of various industrial enterprises. Therefore, the growth witnessed within the HRS policy framework is commendable having made agriculture to be the foundation of Chinese national economy (Cheng, 2000).

Table 3: Changes in the Chinese economic structure in percentages (\%)

\begin{tabular}{lcccccc}
\hline & 1978 & 1980 & 1985 & 1990 & 1995 & 2000 \\
\hline $\begin{array}{l}\text { Share in GDP } \\
\quad \text { Agriculture }\end{array}$ & 28.1 & 30.1 & 28.4 & 27.1 & 20.5 & 16.4 \\
$\quad \begin{array}{l}\text { Industrial } \\
\quad \text { Service }\end{array}$ & 48.2 & 48.5 & 43.1 & 41.6 & 48.8 & 50.2 \\
$\begin{array}{l}\text { Share in employment } \\
\quad \text { Agriculture }\end{array}$ & 23.7 & 21.4 & 28.5 & 31.3 & 30.7 & 33.4 \\
$\quad$ Industrial & 70.5 & 68.7 & 62.4 & 60.1 & 52.2 & 50 \\
$\quad \begin{array}{l}\text { Service } \\
\text { Share in total exports }\end{array}$ & 17.3 & 18.2 & 20.8 & 21.4 & 23 & 22.5 \\
$\begin{array}{l}\text { Agricultural products } \\
\text { Share in total imports }\end{array}$ & 12.2 & 13.1 & 16.8 & 18.5 & 24.8 & 27.5 \\
$\begin{array}{l}\text { Agricultural products } \\
\text { Share of rural population }\end{array}$ & 82.1 & 80.6 & 76.3 & 73.6 & 71.0 & 63.8 \\
\hline
\end{tabular}

Source: NBSC, China Statistical Yearbook (All issues)

It is interesting to further note that the annual production growth rates of major Chinese agricultural products increased rapidly between 1978 to 1984 as reported in Table 4. This tremendous growth has been attributed to the Chinese agricultural and rural sectors great reform of 1978 by many researchers (Kalirajan, Obwona, \& Zhao, 2006; Lin, 1992; Mcmillan, Whalley, \& Zhu, 1989). In utilizing a province-level panel data from 1970 to 1987, (Gong, 2018) found out that HRS was instrumental to the $40 \%$ growth output within the first phase of the great reform 1978-1984. This has also been proven by the works of (Shenggen Fan, Zhang, \& 
Zhang, 2002; Mcmillan et al., 1989). On the other hand, the agricultural sector made enormous and steady contributions towards labour transfer from agricultural to non-agricultural sectors. These contributions measured in terms of labour, capital and total factor productivity has been reported (Fang, Garnaut, \& Song, 1999) to constitute the majority of TFP growth and 21 per cent of per capita GDP growth in the period 1978-90 (Figure 6). Unfortunately, the increase in the growth of industries led to growth reduction in the agricultural sector (Figure 7).

\begin{tabular}{lcccc}
\multicolumn{5}{c}{ Table 4: Annual Growth Rates of China's Agricultural Products in percentages (\%) } \\
\hline & $1950-1969$ & $1970-1977$ & $1978-1984$ & $1985-1998$ \\
\hline Grain & 2.5 & 2.4 & 5.0 & 2.3 \\
$\quad$ Paddy & 2.9 & 2.3 & 4.5 & 1.3 \\
Wheat & 3.4 & 5.0 & 8.5 & 1.9 \\
Corn & 3.1 & 5.9 & 4.6 & 5.8 \\
$\quad$ Soybean & 0.1 & -2.6 & 4.2 & 2.9 \\
Cotton & 6.0 & -1.5 & 19.3 & 0.6 \\
Vegetable & -1.8 & 3.1 & 7.5 & 7.8 \\
Fruit & 5.4 & 6.1 & 7.0 & 12.6 \\
Meat & 14.7 & 4.2 & 9.0 & 8.3 \\
Aquatic & 6.3 & 5.7 & 4.9 & 14.1 \\
products & & & & \\
\hline
\end{tabular}

Source: NBSC, China Statistical Yearbook (All issues).

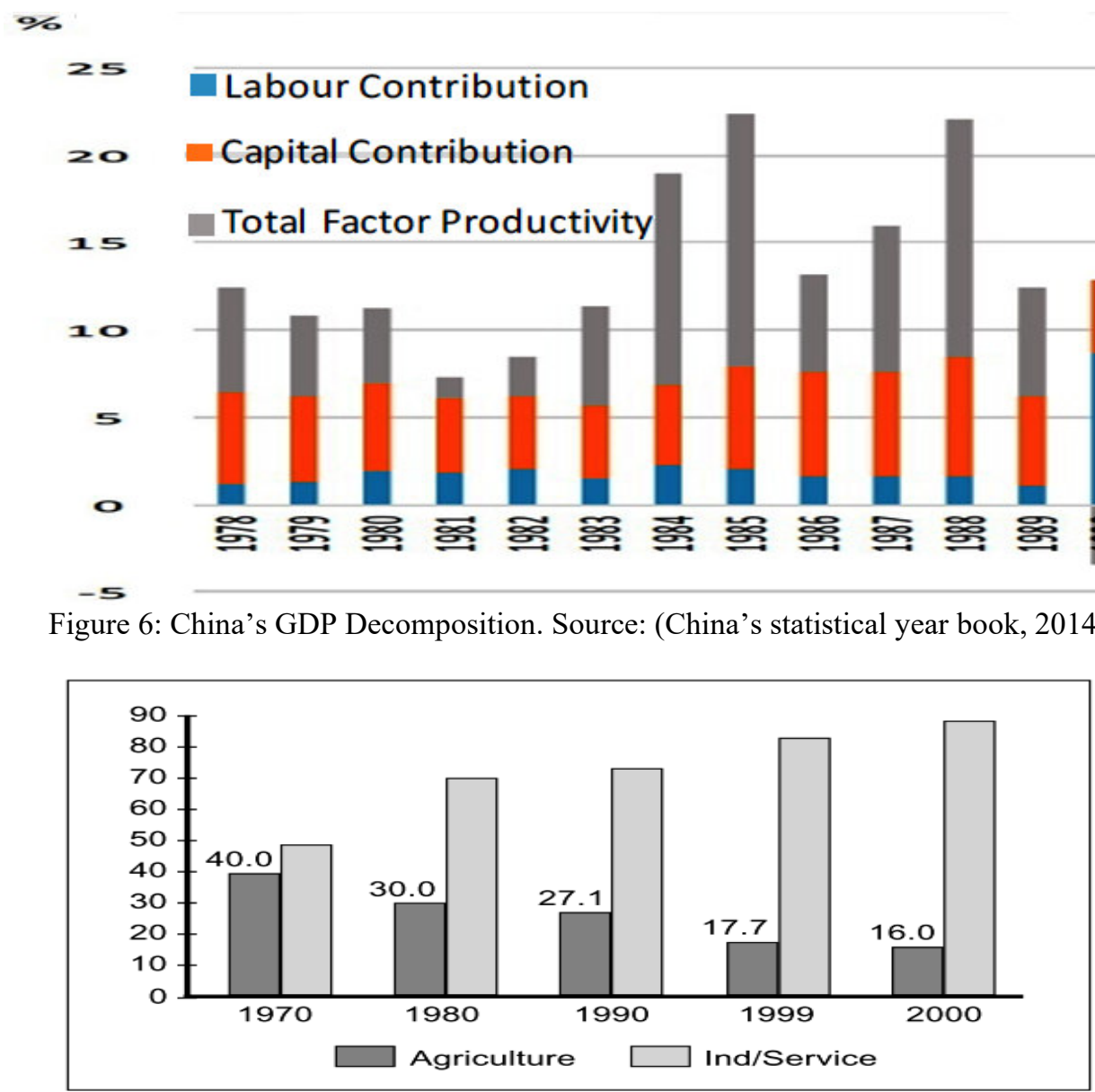

Figure 7: Growth in agriculture and industrialization. Source: (L.X. Zhang, 2001) 


\section{Future Outlook and Conclusion}

Great reform and policy change led to stability in the growth of Chinese agriculture (Zhou, 2013) and should be encouraged among developing nations as a tool that guarantees rural development and economic stability (Cheng, 2000; Ho, 2009; Jiancheng et al., 2008). The HRS is a bottom-up development approach which resulted in tremendous positive change in the Chinese rural and agricultural reform (Huang \& Rozelle, 2001; Marden, 2015). However, at long run it became a major challenge because of land fragmentation which discouraged large scale production, the use of pesticides and agricultural machineries (Chen \& Brown, 2001) and is seen as a hindrance to agricultural development (Tan, Heerink, \& Qu, 2006). It is therefore important to note that every policy has its timeline and it is the responsibility of policy makers to continuously study policies implemented to avoid detrimental effects after huge successes.

Policy change that gave rise to the adoption of household production responsibility system in China has been the focus of agricultural researchers over a long period of time. Its role in the overall development of China can never be neglected just like the role of agriculture in the development of man and his environment can never be over emphasized. International integration is essential for development which encourages and transforms development of people's economy for instance the Chinese opening up. Agricultural sector in no doubt has played major roles in the development of nations and is still making significant changes till date. Developed countries over the years have maintained stable growth while utilizing agriculture as an economic base. The policy change of 1978 in agriculture has tremendously shaped the Chinese economy over the past 40 years making it apt for scholars to research on the basic strategies that were utilized in the implementation of the Chinese household responsibility system. This review has been able to analyse the policy change and agricultural development in China within the 10 years of reform. In it we have been able to understand how the policy change occurred, the major strategies that were adopted for implementation and achievements of the agricultural sector through household responsibility system which would serve as a lesson to developing countries and policy makers in the future.

\section{REFERENCES}

Ahmad, E., \& Wang, Y. (1991). Inequality and Poverty in China - Institutional Change and Public-Policy, 1978 to 1988. World Bank Economic Review, 5(2), 231-257.

Chen, K., \& Brown, C. (2001). Addressing shortcomings in the Household Responsibility System empirical analysis of The Two-Farmland System in Shandong Province. China Economic Review, 12, 280-292. https://doi.org/10.1016/S1043-951X(01)00045-1

Cheng, G. (2000). China's Agriculture within the World Trading System, 81-104. Retrieved from https://ageconsearch.umn.edu/bitstream/55022/2/Cheng Chapter 4.pdf

Cheng, G. (2004). China's Agricultural Policies and Rural Development, 7. Retrieved from https://www.oecd.org/tad/agricultural-policies/37700749.pdf

China's statistical year book. (2014). China Statistical Yearbook Database-Statistical Yearbook Navigation China Statistical Yearbooks Database Logic, 62791819.

Chow, G. C. (2018). Chinas Economic Transformation. JSTOR, 1-25.

Dandan, N. (2018). THE FARMER WHO CHANGED CHINA FOREVER. Retrieved February 1, 2019, from https://www.sixthtone.com/news/1002783/the-farmer-who-changed-china-forever

Deng Xiaoping. (1984). 'Building Socialism with a Specifically Chinese Character. The People's Daily. Beijing. Retrieved from http://newlearningonline.com/new-learning/chapter-4/deng-xiaoping-socialism-withchinese-characteristics

Douglas Hurt, R. (2010). American and Chinese Agricultural Policy since 1949: An Overview. Procedia Social and Behavioral Sciences 41, 41, 6692-6701. https://doi.org/10.1016/j.sbspro.2010.05.014

Fan, Shenggan, \& Pardey, P. G. (1997). Research, productivity, and output growth in Chinese agriculture. Journal of Development Economics, 53(1), 115-137. https://doi.org/10.1016/S0304-3878(97)00005-9

Fan, Shenggen, Zhang, L., \& Zhang, X. (2002). Growth, inequality, and poverty in rural China: The role of public investments. Research Report 125. Research Report 125, 82. Retrieved from http://ebrary.ifpri.org/utils/getfile/collection/p15738coll2/id/87927/filename/87928.pdf

Fang, C., Garnaut, R., \& Song, L. (1999). 40 years of China's reform and development: How reform captured China's demographic dividend. China's 40 Years of Reform and Development: 1978-2018, 5-25. https://doi.org/10.22459/cyrd.07.2018.01

Fang, C., Garnaut, R., Song, L., \& River, Y. (2019). China's 40 Years of Reform and Development : 1978 2018. Australian National University, 1-10.

Garnaut, R., \& Song, L. (2006). The Turning Point in China's Economic Development. The Turning Point in China's Economic Development. https://doi.org/10.26530/oapen_459745

Garnaut, R., Song, L., \& Fang, C. (2018). China's 40 Years of Reform and Development: 1978-2018. Retrieved from http://press-files.anu.edu.au/downloads/press/n4267/pdf/book.pdf?referer=4267 
Ghinoi, S., Wesz Junior, V. J., \& Piras, S. (2018). Political debates and agricultural policies: Discourse coalitions behind the creation of Brazil's Pronaf. Land Use Policy, 76(January), 68-80. https://doi.org/10.1016/j.landusepol.2018.04.039

Gong, B. (2018). Agricultural reforms and production in China: Changes in provincial production function and productivity in 1978-2015. Journal of Development Economics, 132(April 2017), 18-31. https://doi.org/10.1016/j.jdeveco.2017.12.005

Ho, P. (2009). BEYOND DEVELOPMENT ORTHODOXY: CHINESE LESSONS IN PRAGMATISM. JSTOR, 176-210. Retrieved from https://www.jstor.org/stable/j.ctt46n0g6.12

Hofman, B. (2018). Reflections on the forty years of China's reform.

Huang, J., \& Rozelle, S. (2001). Trade Liberalization, Rising Imports and China's Food Economy: The Case of Soybeans. Retrieved

from http://citeseerx.ist.psu.edu/viewdoc/download?doi=10.1.1.615.3520\&rep=rep1\&type=pdf

IMF. (2018). World Economic Outlook (October 2018) - Real GDP growth. Retrieved March 27, 2019, from https://www.imf.org/external/datamapper/NGDP_RPCH@WEO/CHN

Jiancheng, C., Jinbao, L., Shaoyong, F., \& Qiang, L. (2008). Chinese Agricultural Policies in Thirty Years and Analysis on the Effects. China Population, Resources and Environment, 18(5), 1-6. https://doi.org/10.1016/S1872-583X(09)60016-4

Kalirajan, K. P., Obwona, M. B., \& Zhao, S. (2006). A Decomposition of Total Factor Productivity Growth: The Case of Chinese Agricultural Growth before and after Reforms. American Journal of Agricultural Economics, 78(2), 331. https://doi.org/10.2307/1243706

L.X. Zhang. (2001). AGRICULTURAL AND RURAL DEVELOPMENT IN CHINA. Retrieved from http://pubs.iclarm.net/Pubs/china/pdf/china_agricultural.pdf

Lau, L. J., \& Zheng, H. (2017). How much slack was there in the Chinese economy prior to its economic reform of 1978? China Economic Review, 45, 124-142. https://doi.org/10.1016/j.chieco.2017.06.003

Li, Z. (2015). Chinese Comprehensive Rural Reform: Institutional Vicissitude, Theoretic Framework and Content Structure. Journal of Northeast Agricultural University, 22(3), 79-90. https://doi.org/10.1016/S1006-8104(16)30010-1

Lin, J. Y. (1992). Rural reforms and agricultural growth in China. Journal of The American Economic Review, $82(1), 34-51$.

Lopez, R. A., He, X., \& De Falcis, E. (2017). What Drives China's New Agricultural Subsidies? World Development, 93, 279-292. https://doi.org/10.1016/j.worlddev.2016.12.015

Loren, B., Hsieh, C. T., \& Zhu, X. (2008). Growth and structural transformation in China. China's Great Economic Transformation. https://doi.org/10.1017/CBO9780511754234.018

Marden, S. (2015). Agriculture, development and structural change in reform-era China. Retrieved from http://etheses.Ise.ac.uk/3264/1/Marden_Agriculture_development_and_structural.pdf

Mcmillan, J., Whalley, J., \& Zhu, L. (1989). The Impact of China', s Economic Reforms on Agricultural Productivity Growth John Whalley and Lijing Zhu. Journal of Political Economy, 97(4), 781-807.

Meng, B. G. and X. (2018). Rural to Urban Migration and Migrants' Labourmarket performance, 2008-16. JSTOR, 21, 399-404.

Morrison, W. M. (2018). China's Economic Rise: History, Trends, Challenges, and Implications for the United States. Retrieved from www.crs.gov

Tan, S., Heerink, N., \& Qu, F. (2006). Land fragmentation and its driving forces in China. Land Use Policy, 23, 272-285. https://doi.org/10.1016/j.landusepol.2004.12.001

Tisdell, C. (2008). Thirty Years of Economic Reform and Openness in China: retrospect and Prospect.

Xiao-qiang, J., Mongol, N., \& Fu-suo, Z. (2018). The transformation of agriculture in China : Looking back and looking forward. Journal of Integrative Agriculture, 17(4), 755-764. https://doi.org/10.1016/S20953119(17)61774-X

Yang, W. (2006). Reforms, Structural Adjustments, and Rural Income in China. China Perspectives, 63. Retrieved from https://journals.openedition.org/chinaperspectives/575

Yuankai, T. (2005). China's First Rural Reform. Bijing Review.

Zhao, J., \& Tang, J. (2018). Understanding agricultural growth in China: An international perspective. Structural Change and Economic Dynamics. https://doi.org/10.1016/j.strueco.2018.03.006

Zhou, L. (2013). China's Agricultural Development: Achievements and Challenges. ANU Press. Retrieved from https://about.jstor.org/terms 